\title{
DEFINIÇÃO DAS UNIDADES DE RESPOSTA HIDROLÓGICA NA BACIA HIDROGRÁFICA DO RIO SANTA MARIA- RS
}

\author{
Romario Trentin \\ Universidade Federal de Santa Maria - UFSM \\ Professor do Departamento de Geociências \\ romario.trentin@gmail.com \\ Luís Eduardo de Souza Robaina \\ Universidade Federal de Santa Maria - UFSM \\ Professor do Departamento de Geociências \\ lesrobaina@yahoo.com.br \\ François Laurent \\ Le Mans Université - França \\ Professor do Curso de Geografia \\ francois.laurent@univ-lemans.fr
}

\begin{abstract}
RESUMO
O modelo hidrológico Soil and Water Assessment Tool (SWAT) representa um modelo computacional que conjuga uma série de parâmetros físicos e permite simular diversos cenários com variadas condições de manejo do solo e de uso da terra. Este trabalho apresenta uma discussão sobre o método de geração e as características de cada Unidades Hidrológicas geradas no modelo na bacia hidrográfica do rio Santa Maria. A partir das sub-bacias se estabelece os cruzamentos espaciais dos dados de solos, uso da terra, declividade, gerando novas delimitações espaciais chamadas Unidades de Resposta Hidrológica (URH). Para as classes de declividade da área de estudo, foram definidos os limites de 5 e 15\%. O mapa base de solos é do IBGE com descrições dos boletins técnicos no Ministério da Agricultura. O uso da terra do IBGE do ano de 2010, sendo que os tipos de usos foram relacionados aos tipos já cadastrados no banco de dados do ArcSWAT. As URHs representam uma combinação do tipo de solo, declividade, uso da terra. Cada subbacia apresenta unidades hidrológicas características. A análise das características da Bacia Hidrográfica do Rio Santa Maria permitiu avaliar que as unidades de respostas hidrológicas geradas representam de forma satisfatória as heterogeneidades presentes.
\end{abstract}

Palavras-chave: Modelagem. SIG. URH. SWAT. Banco de dados.

\section{DEFINITION OF HYDROLOGICAL RESPONSE UNITS IN THE HYDROGRAPHIC BASIN OF RIO SANTA MARIA- RS}

\begin{abstract}
The hydrological model Soil and Water Assessment Tool (SWAT) represents a computational model that combines a series of physical parameters and allows simulating various scenarios with varying conditions of soil management and land use. This work presents a discussion about the generation methodology and the characteristics of each Hydrological Units generated in the model in the Santa Maria River Basin. From the subbasins, spatial crossings of soil data, land use, slope are established, generating new spatial boundaries called Hydrological Response Units (HRU). For the slope classes of the study area, the limits of 5 and $15 \%$ were defined. The soil base map is from IBGE with descriptions of technical bulletins at the Ministry of Agriculture. IBGE's land use in 2010, and the types of uses were related to the types already registered in the ArcSWAT database. HRUs represent a combination of soil type, slope, land use. Each sub-basin has characteristic hydrological units. The analysis of the Santa Maria River Basin characteristics allowed to evaluate that the units of hydrological responses generated represent satisfactorily the heterogeneities present.
\end{abstract}

Keywords: Modeling. GIS. HRU. SWAT. Database.

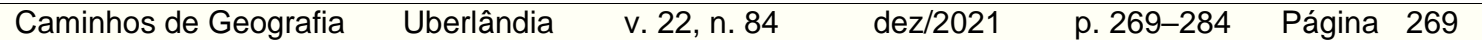




\section{INTRODUÇÃO}

A bacia hidrográfica é uma unidade de planejamento, pois possibilita ter um ponto de controle do fluxo de matérias e energia entre o solo e água, estabelecendo relações entre nutrientes e poluentes presentes nos sistemas. Segundo Tucci (2002), a bacia hidrográfica é um sistema físico onde a entrada é o volume precipitado e a saída é o volume de água escoado pelo exutório, diminuindo pela evapotranspiração e diminuindo ou aumentado pelas transferências interbacias, podendo-se analisar o processo de transformação de chuva em vazão.

No Brasil a utilização da bacia hidrográfica como unidade de planejamento está indicada pela Resolução do Conselho Nacional de Meio Ambiente CONAMA) $n^{\circ}$ 001/1986, Artigo $5^{\circ}$, inciso III, que afirma: "...os limites da área geográfica a ser direta ou indiretamente afetada pelos impactos, denominada área de influência do projeto, considerando, em todos os casos, a bacia hidrográfica na qual se localiza" (Instituto Brasileiro do Meio Ambiente e dos Recursos Naturais Renováveis - IBAMA, 1986, p. 2.548).

Para o planejamento e gestão dos recursos hídricos os modelos hidrológicos são ferramentas essenciais. Conforme Tucci (1998) e Renno e Soares (2000), o modelo hidrológico é uma ferramenta que permite (por meio de equações) representar, entender e simular o comportamento de uma bacia hidrográfica, ajudando a entender o impacto das mudanças no uso da terra ou das condições climáticas e prever alterações futuras nas bacias hidrográficas.

Existem vários modelos hidrológicos, como os que são baseados no conceito de Unidades de Respostas Hidrológicas (URHs), uma área espacial com características semelhantes no seu comportamento por consequência da similaridade dos fatores dominantes. Dentre eles, o modelo hidrológico Soil and Water Assessment Tool (SWAT) representa um modelo computacional que conjuga uma série de parâmetros físicos que permite simular diversos cenários com variadas condições de manejo do solo, transporte de sedimentos e transporte de químicos agrícolas em uma bacia hidrográfica. O SWAT é baseado no equilíbrio hídrico dentro da bacia e, portanto, independente da natureza do estudo realizado o seu funcionamento será sempre uma função do balanço hídrico existente na bacia hidrográfica. O modelo foi desenvolvido pelo Agricultural Research Service/United States Department of Agriculture (ARS/USDA) dos Estados Unidos (ARNOLD et al., 1998). Conforme GASSMAN et al. (2007) foi concebido a partir da mescla dos modelos SWWRB (Simulator for Water Resources in Rural Basins) e ROTO (Routing Outputs to Outlet). Neste modelo há a integração entre interfaces de SIG (Sistema de Informação Geográfica) e equações matemáticas que representam o comportamento hidrológico da bacia.

Os constantes trabalhos de qualificação e adaptação do modelo, desde sua criação na década de 1990, permitiram sua aceitação internacional como ferramenta para modelagem de bacia hidrográfica. A aplicação desse modelo tem se expandido no mundo, especialmente nos Estados Unidos da América (EUA) e na Europa. No Brasil, conforme GARBOSSA et al (2011) um dos primeiros trabalhos foi desenvolvido por Oliveira e Medeiros (1999), em um estudo hidrosedimentológico.

Entretanto, conforme Bressiani et al. (2015), a utilização do SWAT no Brasil teve um grande crescimento na última década, com trabalhos que buscaram verificar desde a capacidade do modelo de representar satisfatoriamente as bacias hidrográficas brasileiras, até análises mais complexas, como a avaliação do impacto causado em bacias (alteração do volume de água escoado superficialmente, e transporte de sedimentos e aditivos agrícolas) pela mudança do uso do solo ou pelo desmatamento de florestas. No Rio Grande do Sul o modelo SWAT tem sido usado como suporte para o planejamento de uso para qualidade da água em área de cultivos e, também em áreas com eucaliptos (Uzeika et al., 2012; Bonumá 2011; Bonumá et al 2013; Rodrigues et al., 2015). Na bacia do rio Ibicuí, o trabalho de modelagem hidrológica com utilização do SWAT foi desenvolvido por Fauconnier (2017) na sua dissertação de mestrado.

Este trabalho apresenta uma discussão sobre o método de geração e as características de cada Unidade Hidrológica gerada no modelo na bacia hidrográfica do rio Santa Maria (Figura 01). As URH's são utilizadas como unidades espaciais para os cálculos realizados pelo modelo SWAT e representam áreas com características físicas iguais, com semelhante resposta hidrológica.

\section{MÉTODO DE OBTENÇÃO DOS DADOS E GERAÇÃO DAS URHS}

O processamento do modelo SWAT inicia com a delimitação da bacia e das sub-bacias geradas a partir do Modelo Digital de Elevação (MDE) da área de estudo. O MDE foi obtido do SRTM 30m com rios e bacias gerados automaticamente. As sub-bacias são geradas com o auxílio das ferramentas hidrológicas do SIG que calculam a direção do fluxo nos pixels, a acumulação de fluxo e, por meio da determinação do valor mínimo de fluxo acumulado, determina-se os cursos d'água, com seus pontos de interseção entre

$\begin{array}{llllll}\text { Caminhos de Geografia } & \text { Uberlândia - MG } & \text { v. 22, n. 84 } & \text { Mês/Ano } & \text { p. 269-284 } & \text { Página } 270\end{array}$


canais, bem como seus exutório. A partir da determinação dos pontos de exutório, definidos automaticamente na geração dos cursos d'água, ou editados manualmente por meio da inserção ou exclusão dos pontos, a fim de melhor definir as sub-bacias a serem analisadas, elas são delimitadas automaticamente. Na etapa seguinte são inseridos os dados de solos, uso da terra, e determinação das classes de declividade. O modelo executa os cruzamentos espaciais dos dados de solos, uso da terra e declividade, gerando novas delimitações espaciais chamadas Unidades de Resposta Hidrológica (URH), representando assim, discretizações do espaço interno das sub-bacias.

Figura 01 - Localização da Bacia Hidrográfica do Rio Santa Maria

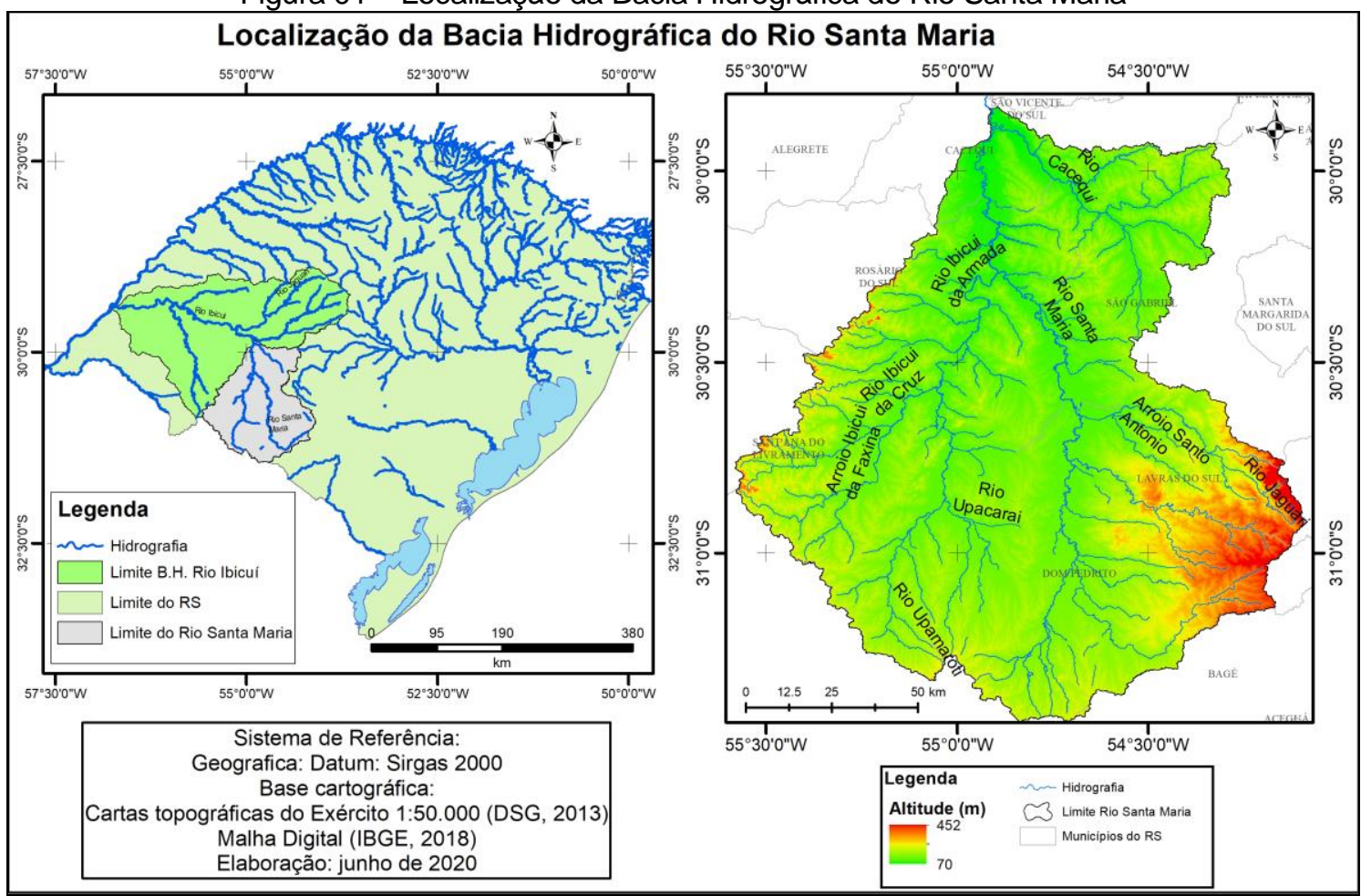

Org: os autores

As classes de declividade foram definidas de acordo com proposta do Instituto de Pesquisas Tecnológicas - IPT (1981) que trabalha com classificação de formas de relevo e utiliza os limites de 5 e $15 \%$ de declividade na definição das formas. O mapa de declividade é gerado por meio das ferramentas de análise espacial do SIG, por meio dos complementos do ArcSWAT, sendo gerado o plano de informação da declividade em porcentagens e reclassificado conforme as classes estabelecidas pelo usuário. $O$ ArcSWAT é um complemento de distribuição gratuito que foi implementado no SIG ArcMap® licenciado para o Programa de Pós-Graduação em Geografia da Universidade Federal de Santa Maria.

Com relação aos solos as análises hidrológicas envolvem a avaliação da infiltração de água no solo, condutividade, armazenamento e relações planta-água. Definir os efeitos hidrológicos da água no solo requerem estimativa da água no solo características do potencial hídrico e condutividade hidráulica usando variáveis como textura, matéria orgânica (MO) e estrutura. Para isso o modelo SWAT requer um banco de dados com diversas informações que são divididos em duas partes: i) parâmetros do tipo de solo; e ii) parâmetros da camada do solo (Figura 02).

Os parâmetros do tipo de solo são os seguintes: a) nome do solo (SNAM); b) número de camadas (NLAYERS); c) grupo hidrológico do solo (HYDGRP) - Grupo A - Solos arenosos profundos com alta capacidade de infiltração e geram pequenos escoamentos, Grupo B - Solos franco arenosos pouco profundos, tendo menor capacidade de infiltração e geram maiores escoamentos do que o solo A, Grupo C - Solos franco argilosos com menor capacidade de infiltração e geram maiores escoamento do que $\mathrm{A} e$ B, Grupo D - Solos argilosos expansivos; tem baixa capacidade de infiltração e geram grandes escoamentos; d) profundidade total (SOL_ZMX); e) porosidade do solo indicado pelo parâmetro da fração 
da porosidade em que os ânions são excluídos (ANIO_EXCL) e máximo volume de fissura do perfil do solo expresso como uma fração do total do volume do solo (SOL_CRK).

Figura 02 - Interface sobre a parametrização dos solos no modelo

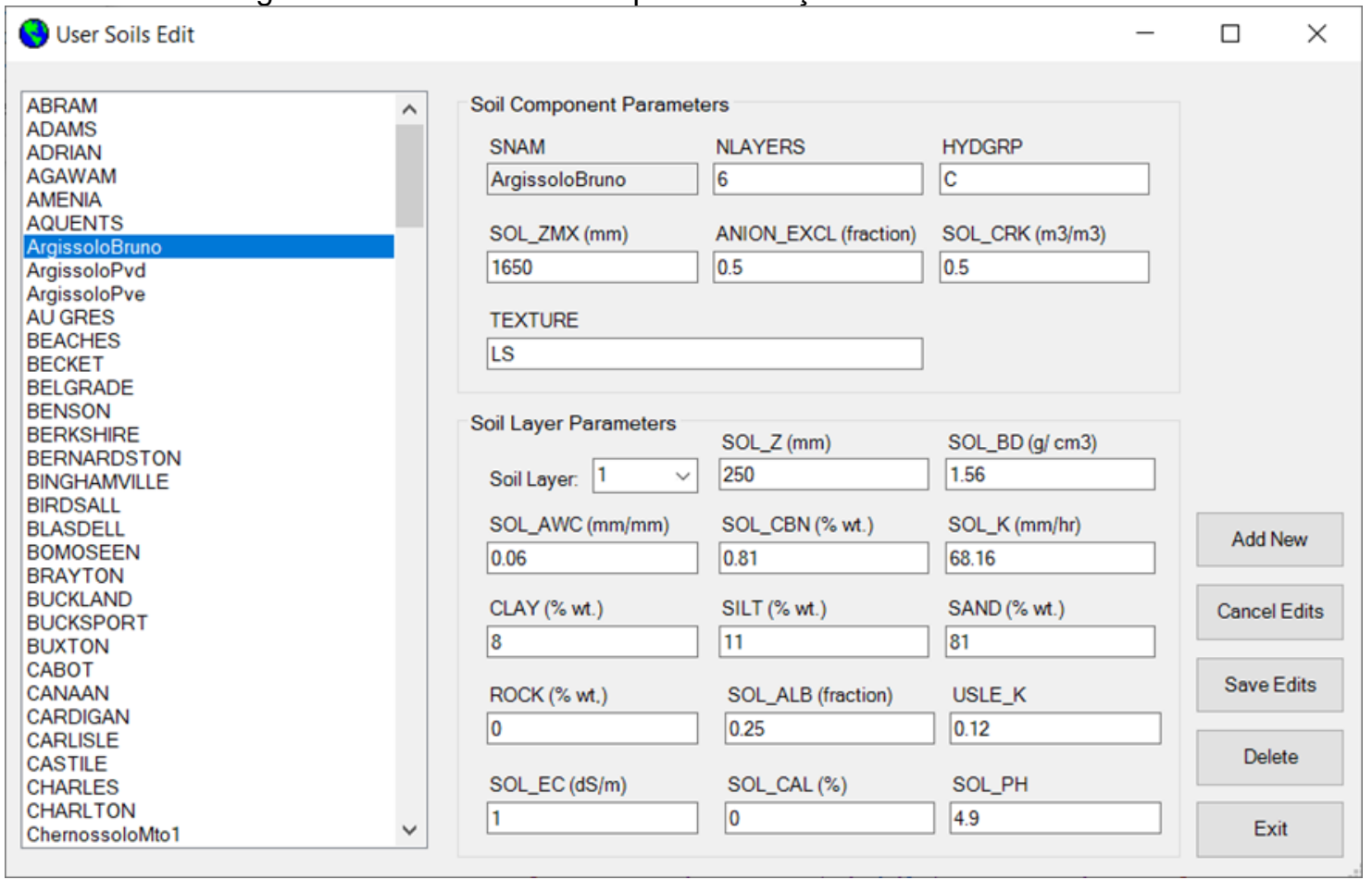

Fonte: STONE ENVIRONMENTAL INC \& TEXAS A\&M (2012)

Os parâmetros relacionados a cada camada são os seguintes: a) profundidade da superfície até o fundo da camada (SOL Z); b) densidade da massa úmida (SOL_BD); c) capacidade de água disponível na camada (SOL_AWC); d) conteúdo orgânico das camadas do solo (SOL_CBN); e) condutividade hidráulica saturada da camada (SOL_K); f) porcentagem de argila; g) porcentagem de silte; h) porcentagem de areia; i) porcentagem de rocha; j) albedo do solo úmido (SOL_ALB); e k) fator de erodibilidade da camada (USLE_K); condutividade elétrica (SOL_EC); conteúdo de carbonato de cálcio (SOL_CAL); pH do solo (SOL_PH).

A implementação dos tipos e parâmetros dos solos no banco de dados, foi executada de forma manual, onde são criados os tipos de solos com suas referidas características, para que posteriormente, estes solos cadastrados no banco de dados possam ser utilizados no modelo para o cruzamento e definição das URHs. Na implementação das informações no banco de dados do SWAT, deve-se atentar às configurações regional de numeração e datas que deve estar baseado no sistema dos EUA.

O mapeamento de solos em escala 1:250.000, foi definido por meio do trabalho disponibilizado pelo IBGE (2002, 2015) e a utilização dos perfis de solo realizado no Levantamento de Reconhecimento dos Solos do Estado do Rio Grande do Sul, produzido pelo Ministério da Agricultura no Boletim Técnico de N. ${ }^{\circ 30}$ (MINISTÉRIO DA AGRICULTURA, 1973).

Os dados hidrológicos como infiltração, condutividade, água disponível, relação água-planta, densidade efetiva foram obtidas a partir de regras de transferência, que consistem em cálculos estabelecidos em planilha Excelß desenvolvida por Saxton and Rawls (2006) que utiliza a textura e matéria orgânica no solo para o cálculo. Correlações estatísticas entre textura do solo, potencial hídrico do solo e a condutividade hidráulica pode fornecer estimativas suficientemente precisas para muitas análises e decisões. O Excel®é uma das aplicações do Office $365 \AA$ com licenças dos pesquisadores do Laboratório de Geologia Ambiental da Universidade Federal de Santa Maria.

Para a elaboração do mapa de uso da terra na BHRSM foi utilizado o mapa de uso e cobertura da terra do IBGE do ano de 2010 (IBGE, 2010), sendo que os tipos de usos foram relacionados aos valores das

$\begin{array}{llllll}\text { Caminhos de Geografia } & \text { Uberlândia - MG } & \text { v. 22, n. } 84 & \text { Mês/Ano } & \text { p. 269-284 Página } 272\end{array}$


variáveis disponibilizadas pelo banco de dados do ArcSWAT, por meio das características de culturas e formações vegetais naturais disponíveis na área de estudo e cadastradas no banco de dados.

A figura 03 apresenta as características das culturas de soja/aveia, cultura características na área de estudo, disponíveis no banco de dados do modelo SWAT. Para obtenção dessas variáveis, foram realizados levantamentos de campo com equipamento de posicionamento global onde foram coletados pontos georreferenciados em cada uso da terra. Posteriormente foi realizada a conferência dos dados de uso do solo obtidos no campo com os determinados pelo algoritmo de classificação das imagens.

Figura 03 - Interface de entrada no programa das variáveis sobre uso e cobertura da terra

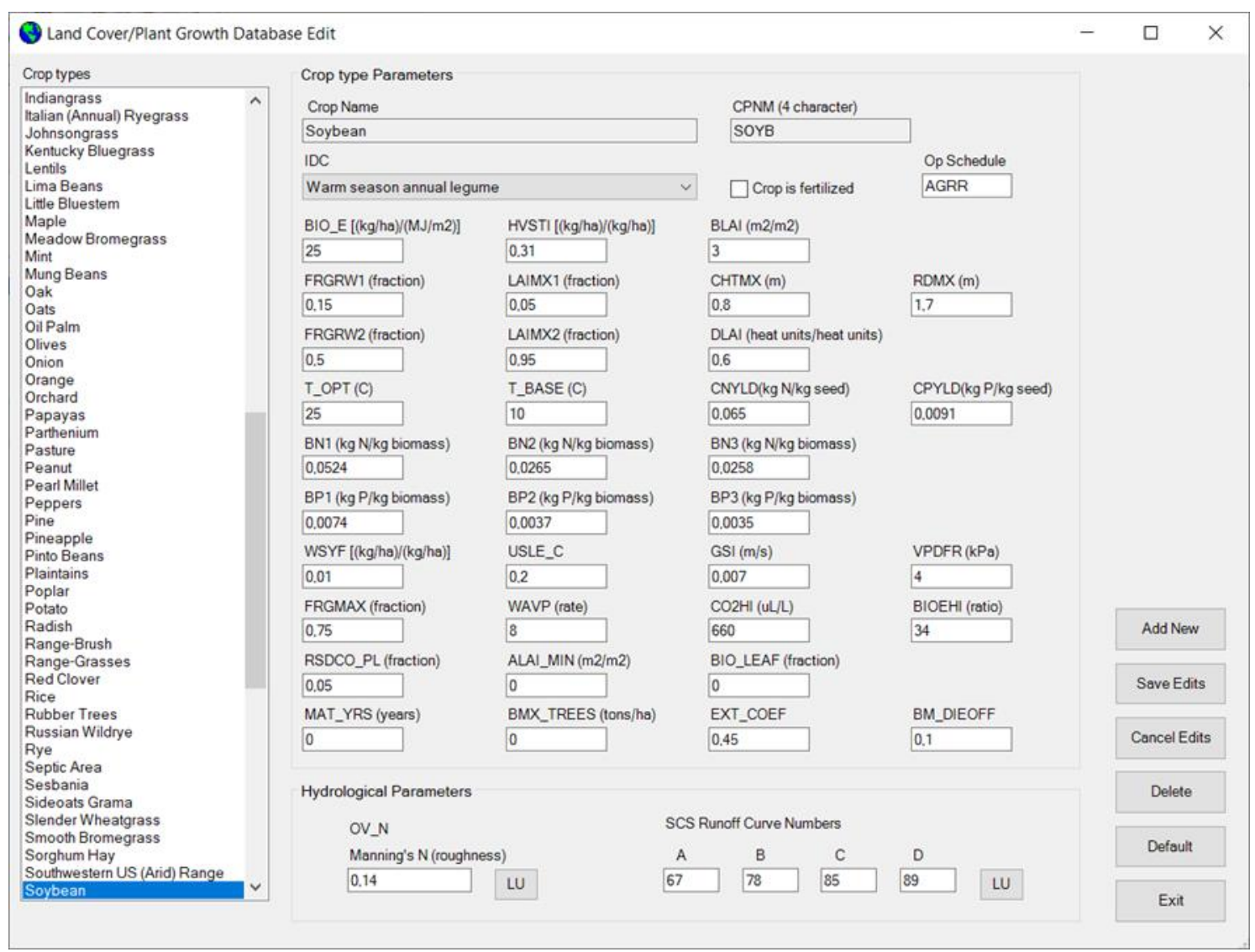

Fonte: STONE ENVIRONMENTAL INC \& TEXAS A\&M (2012)

Após a inserção dos dados no sistema, é realizado o cruzamento destes com as sub-bacias anteriormente definidas. Para o cruzamento dos dados, realizou-se a definição dos índices de influência para cada parâmetros, determinando na geração dos URH a participação dos solos e declividade de no mínimo 5\% e de todos os tipos de uso da terra presentes na bacia. A figura 04 apresentam um fluxograma síntese das etapas operacionais do ArcSWAT, para a determinação das Unidades de resposta hidrológicas.

Figura 04 - Fluxograma das etapas operacionais do modelo 


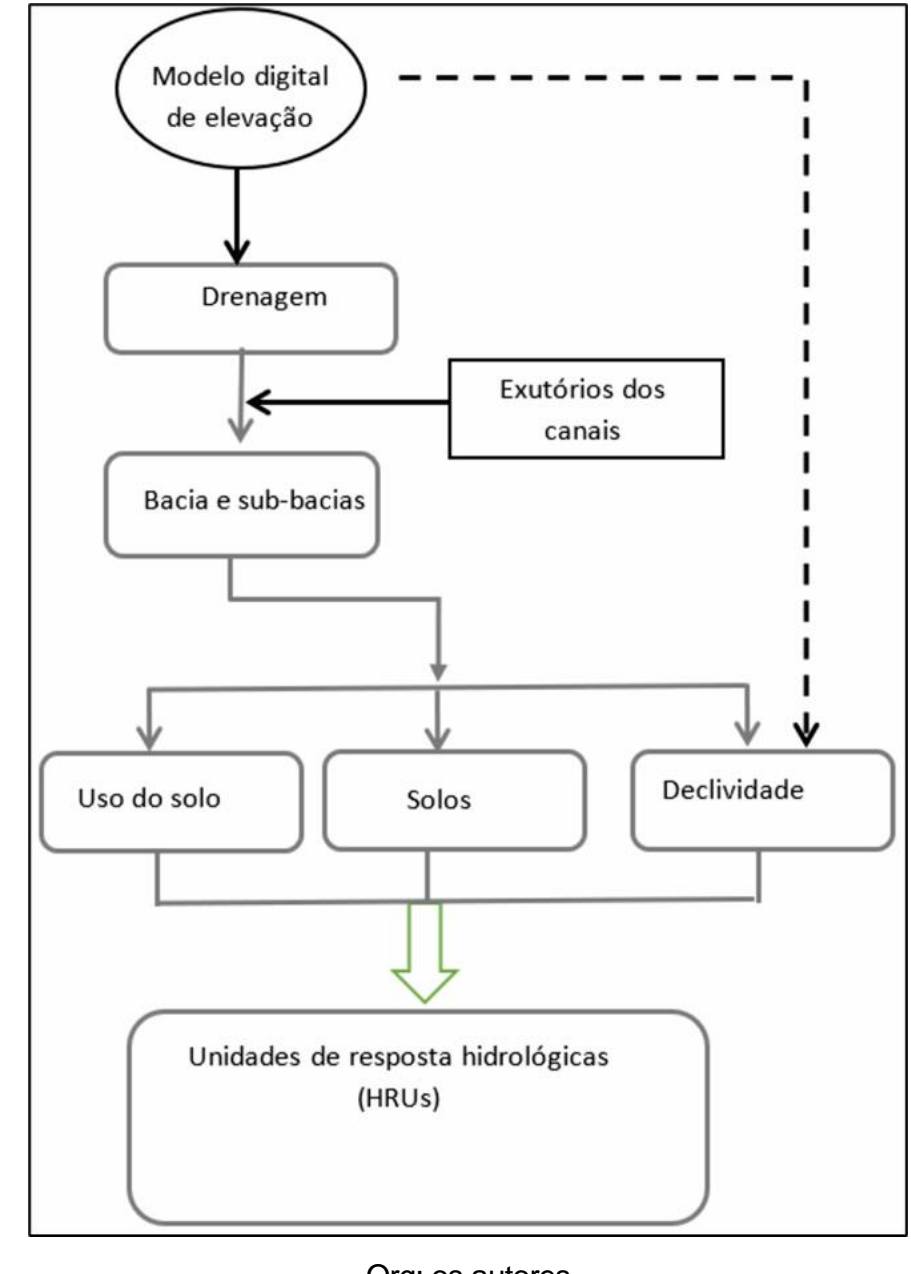

Org: os autores

\section{CARACTERIZAÇÃO DA BACIA DO RIO SANTA MARIA}

A Bacia do rio Santa Maria se localiza no sudoeste do Rio grande do Sul, ocupando uma área de aproximadamente $15.748 \mathrm{~km}^{2}$, entre as coordenadas geográficas $29^{\circ} 47^{\prime}$ a $31^{\circ} 36^{\prime} \mathrm{S}$ e $54^{\circ} 00^{\prime}$ a $55^{\circ} 32^{\prime} \mathrm{W}$. constitui um tributário direto da margem esquerda do rio lbicuí, com rede de drenagem controlada por lineamentos tectônicos e por diferenças litológicas, onde os canais se alojam em porções menos resistentes do terreno. Os principais tributários são rios Upamaroti, Ponche Verde, Santo Antônio, JaguariTaquarembó, Cacequi, Ibicuí da Cruz, Ibicuí da Faxina e Ibicuí da Armada.

A Bacia do Rio Santa Maria é composta pela região morfoestrutural descrita no Projeto RADAM BRASIL (IBGE, 1986) do Embasamento em Estilos Complexos, ocupando na porção do extremo SE, em aproximadamente $10 \%$ de sua área total, e principalmente pela região de Bacias e depósitos Sedimentares formados por rochas e sedimentos em diferentes ambientes deposicionais e por uma pequena área a oeste da bacia do Planalto vulcânico. As formas de relevo predominantes na bacia são colinas ligeiramente onduladas que compõem $49,5 \%$ da bacia total. Essas formas são caracterizadas por amplitudes entre $20 \mathrm{~m}$ e $40 \mathrm{~m}$ e declividade entre $2 \%$ e $5 \%$ representam relevo de aplainamento.

A Figura 05 apresenta os mapas básicos de declividade, solos e uso da bacia hidrográfica do Rio Santa Maria. Conforme pode-se observar, as áreas com inclinações inferiores a 15\% são predominantes na bacia hidrográfica. As declividades superiores a 15\% ocorrem associadas às porções de divisores de água nas porções leste formando morros e morrotes isolados e na porção oeste da bacia hidrográfica junto a Serra do Caverá (Figura 06).

$\mathrm{Na}$ bacia do rio Santa Maria encontra-se os seguintes solos: Planossolos, Argissolos, Luvissolos, Chernossolos, Neossolos. Os Planossolos ocorrem nas planícies de inundação dos principais cursos d'água e estão representados por Planossolo SxE2, Planossolo SxE1, Planossolo SxE1 (Figura 07a). O Planossolo SxE2 é constituído por solos negros, imperfeitamente drenados, com nítido contraste entre os horizontes. Na porção inferior do B a estrutura é em blocos angulares formada pela interseção dos

$\begin{array}{llllll}\text { Caminhos de Geografia } & \text { Uberlândia - MG } & \text { v. 22, n. } 84 & \text { Mês/Ano } & \text { p. 269-284 } & \text { Página } 274\end{array}$


slickensides; O Planossolo SgE1 é solo mal a imperfeitamente drenado, bastante influenciado pela presença da água que ocasiona fenômenos de redução, com o desenvolvimento no perfil de cores cinzentas, características de gleização; Planossolo SxE1 é um solo medianamente profundo, imperfeitamente drenados, com cores bruno e acinzentadas nos horizontes superficiais e amareladas nos mais profundos, com teores elevados da fração silte, mas também com regulares proporções de argilas expansivas.

Figura 05 - Mapas básicos de declividade, solos e uso da bacia hidrográfica do Rio Santa Maria

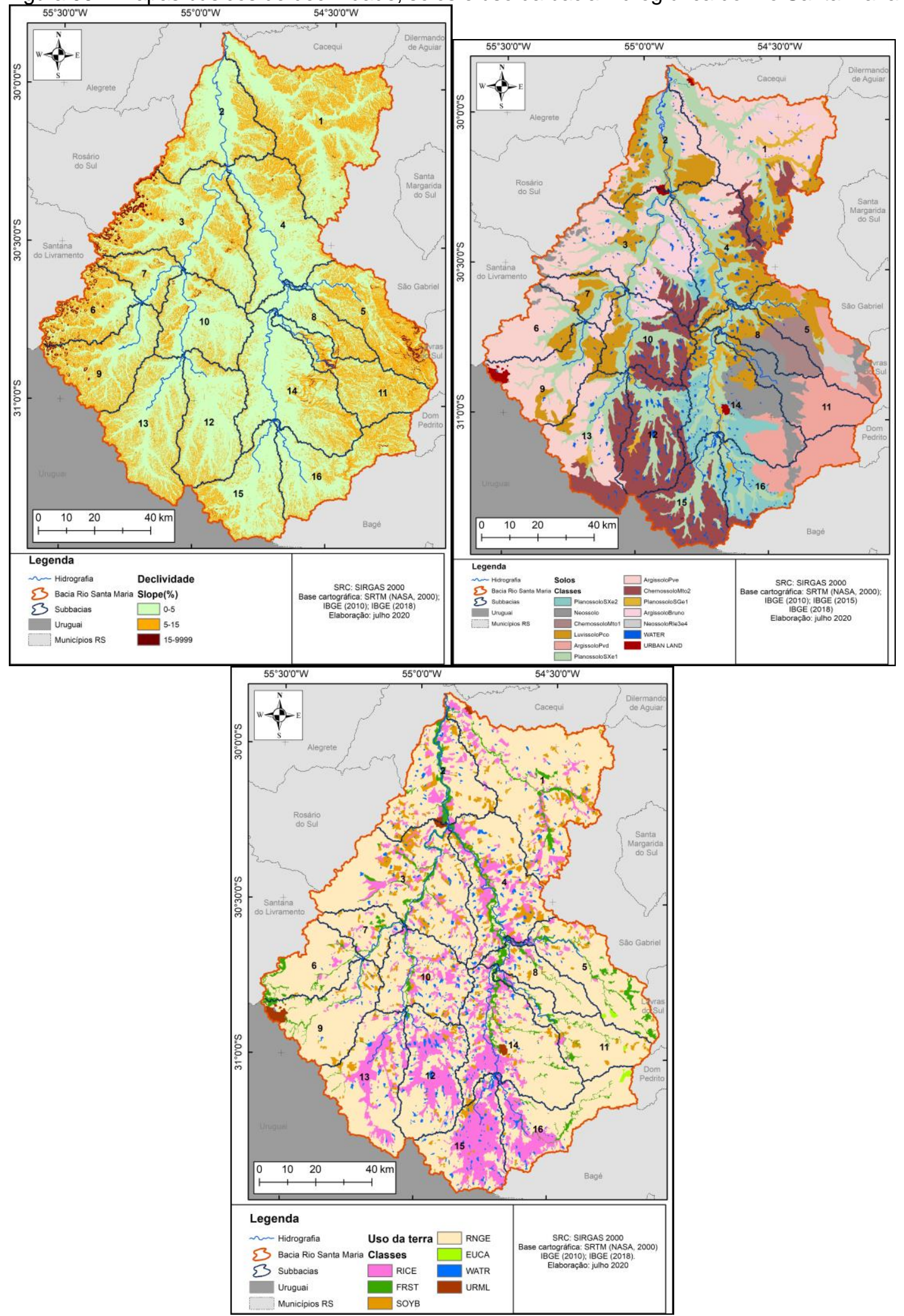


Os Argissolos do tipo Vermelho-amarelo ocorre na porção Oeste e Sul da bacia, os Vermelhos na porção Nordeste e os do tipo Bruno em uma pequena área ao Sul da bacia. Argissolos vermelho-amarelo PVE são constituídos por solos medianamente profundos (em torno de 1 metro), com cores bruno acinzentadas e bruno avermelhadas, franco arenoso no horizonte A e argilosos no B, e moderadamente drenados; Argissolo vermelho PVD são solos profundos, avermelhados, textura superficial arenosa, friáveis e bem drenados; Argissolos do tipo Bruno acizentado APt1 são profundos, arenosos, friáveis em toda a extensão do perfil, moderada e imperfeitamente drenados (Figura 07b).

Os Luvissolos Tco ocorrem associados aos Argissolos, na base da vertente. Os solos têm espessura ao redor de $1 \mathrm{~m}$ e moderadamente drenados, que apresentam um horizonte A proeminente, bruno acinzentado muito escuro, franco, que transaciona abruptamente para um B textural de coloração bruno avermelhada e vermelho amarelada, argilosa.

Os solos do tipo Chernossolos são classificados em dois tipos e ocorrem, predominantemente, sobre substrato de siltitos marinhos na porção centro-norte da bacia. Os Chernossolo MTo1 são solos medianamente profundos, moderadamente drenados, com cores escuras nos horizontes superficiais e bruno amarelados nos mais profundos, textura média e friáveis; Chernossolo MTo2 são solos medianamente profundos, com cores bruno escuras no matiz 10YR, argilosos, poucos porosos e imperfeitamente drenados sendo muito plástico e muito pegajosos quando molhados (Figura 08a)

Os Neossolos ocorrem na região nordeste da bacia sobre substrato de rochas do embasamento e em uma faixa no extremo oeste associada a vulcânicas da Serra do Caverá (Figura 08b).

A estrutura fundiária na BHRSM e o tipo de uso segue a lógica da história da ocupação da região sendo composta, na maioria dos casos, por grandes propriedades, onde as atividades estão ligadas a produção de arroz, soja e gado bovino e ovino. Segundo a classificação definida pela Lei 8.629, de 25 de fevereiro de 1993 são propriedades que variam de 30 ou mais módulos ficais (no Oeste do RS 1 módulo equivale a $28 \mathrm{ha})$.

As pequenas propriedades são pouco expressivas na BHRSM, estando ligadas principalmente a assentamentos da reforma agrária ou em porções da bacia hidrográfica onde não há possibilidade de mecanização da agricultura, geralmente ligada a porções com relevo acidentado.

Foram identificados usos de reflorestamento de espécies exóticas, identificados pela sigla EUCA no modelo, áreas com Floresta Ombrófila Mista nos diferentes estágios de crescimento e de regeneraçãoe associadas às matas de galerias, relacionadas no modelo com FRST e FRSE, respectivamente, áreas de campo com criação, indicadas por RNGE, áreas agrícolas com cultivo de arroz, áreas com cultivo de soja no verão e trigo no inverno, cultivo de soja no verão e pastagens no inverno, relacionadas, respectivamente, com as siglas RICE, SOYB e OATS no banco de dados do SWAT, áreas de aglomerados urbanos (URBAN) e os corpos de água em geral, como rios, córregos, lagos naturais e artificiais (WATER). A Figura 09, apresenta um mosaico de fotografias de campo, ilustrando os diferentes usos da terra presentes na Bacia Hidrográfica.

Figura 06 - Relevo com declividades superiores 15\% associadas à Serra do Caverá na porção oeste da bacia hidrográfica

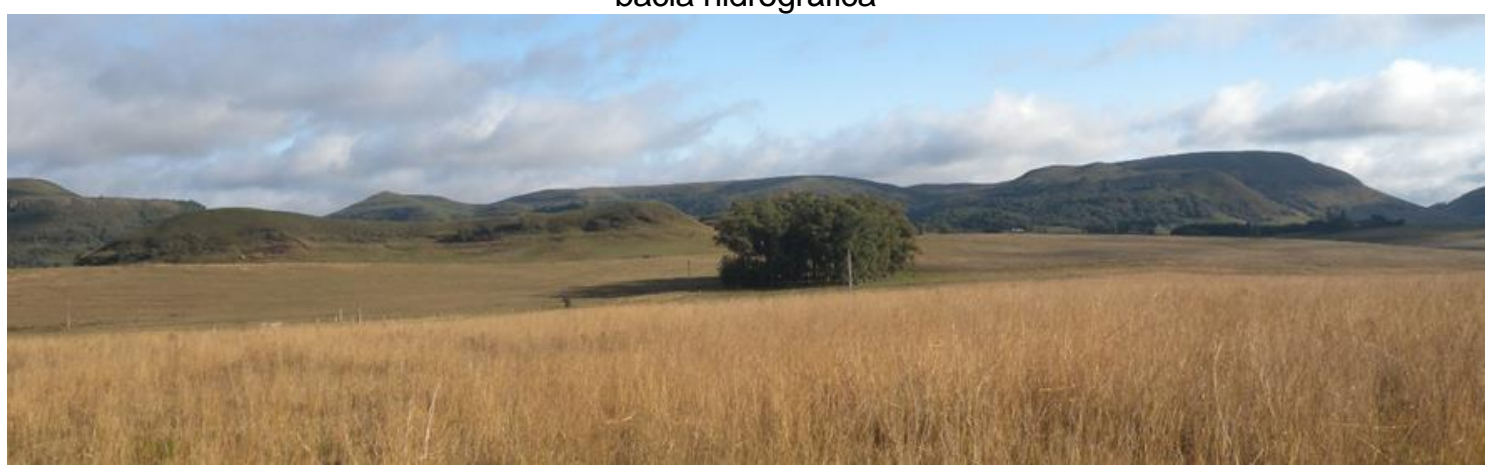

Org: os autores

$\begin{array}{llllll}\text { Caminhos de Geografia } & \text { Uberlândia - MG } & \text { v. 22, n. } 84 & \text { Mês/Ano } & \text { p. 269-284 Página } 276\end{array}$


Figura 07 - Fotografias mostrando o relevo com desenvolvimento dos Planossolos (a) e um perfil de Argissolos (b) na bacia hidrográfica

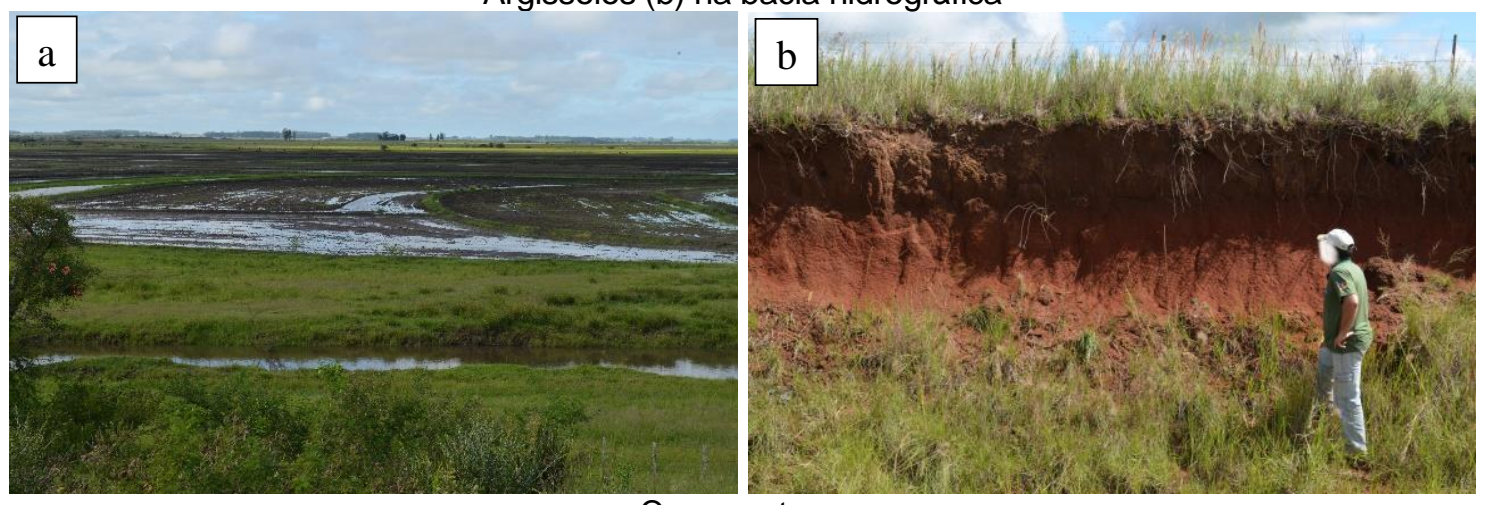

Org: os autores

Figura 08 - Fotografia de ocorrências de Chernossolos sobre siltitos marinhos (a) e Neossolos litólicos e afloramento rochosos
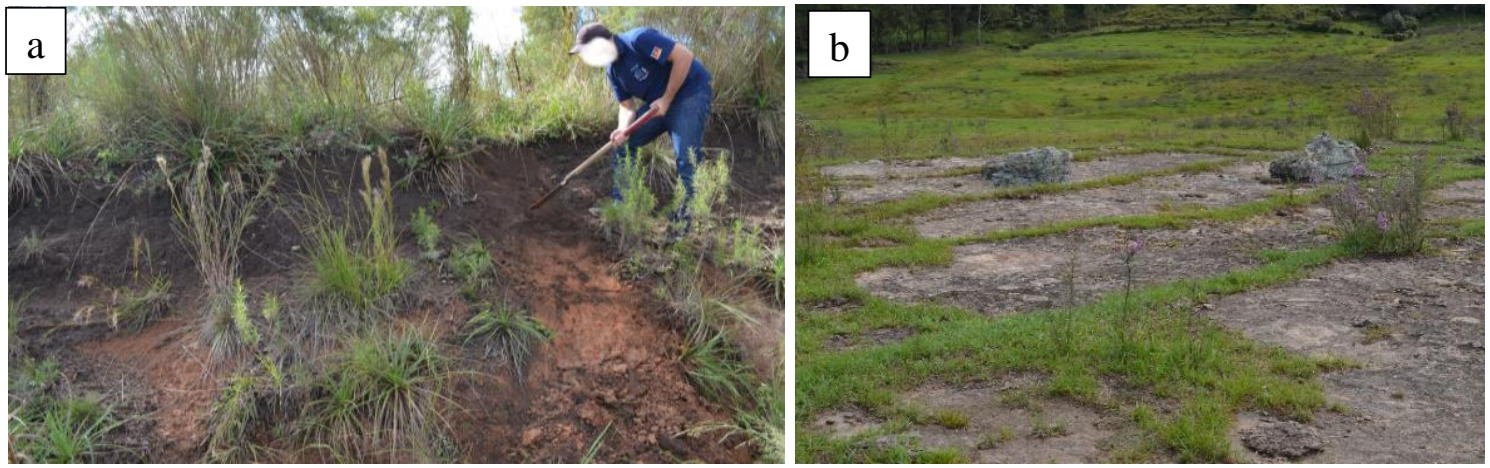

Org: os autores

\section{UNIDADES DE RESPOSTA HIDROLÓGICA}

A Bacia do rio Santa Maria foi dividida em 16 sub-bacias com características de relevo, solos e usos variados indicando as diferentes unidades de resposta hidrológica (Figura 10).

A sub-bacia 1, representada pelo rio Cacequi, está localizada na porção S-SE da bacia com área de $1887,01 \mathrm{~km}^{2}$. Ocorrem 30 unidades hidrológicas, mas predomina relevo que varia de plano a levemente ondulado. Os solos são do tipo Argissolo Pve caracterizado por cores bruno avermelhadas, franco arenoso no horizonte $\mathrm{A}$ e argilosos no $\mathrm{B}$, e moderadamente drenados que ocorrem na meia-vertente ao topo; na base das vertentes ocorrem solos que apresentam um horizonte A proeminente, bruno acinzentado muito escuro, franco, que transaciona abruptamente para um B textural caracterizado como Luvissolos Tco; e nas áreas planas junto a drenagem Planossolos Xe1, solo medianamente profundo, imperfeitamente drenados, com teores elevados da fração silte, mas também com regulares proporções de argilas expansivas. $\mathrm{O}$ uso e ocupação predominante são áreas de campo com criação. $\mathrm{O}$ cultivo mais significativo está representado por lavouras de arroz. As florestas nos diferentes estágios de crescimento e de regeneração ocorrem com uma área aproximada de $66 \mathrm{~km}^{2}$ ao longo do canal principal do rio Cacequi. Nessa sub-bacia ocorre o aglomerado urbano representado pela cidade de Cacequi.

Figura 09 - Usos da terra na bacia hidrográfica. a) Cultura de arroz junto as áreas planas associado aos cursos d'água; b) áreas de pastagem cultivada, com aveia; c) em primeiro plano lavoura de soja e ao junto área urbana de Rosário do Sul; d) área de pastagem com gado em colinas onduladas; e) áreas de campo com campos nativos; f) área de Silvicultura com cultivo de eucaliptos ao lado de uma lavoura de soja; g) açudes utilizado para dessedentação do gado, lago artificial bastante comum na bacia hidrográfica; $h$ ) lavouras de soja recém colhidas com presença de vegetação florestal associada aos cursos d'água

$\begin{array}{llllll}\text { Caminhos de Geografia } & \text { Uberlândia - MG } & \text { v. 22, n. } 84 & \text { Mês/Ano } & \text { p. 269-284 } & \text { Página } 277\end{array}$



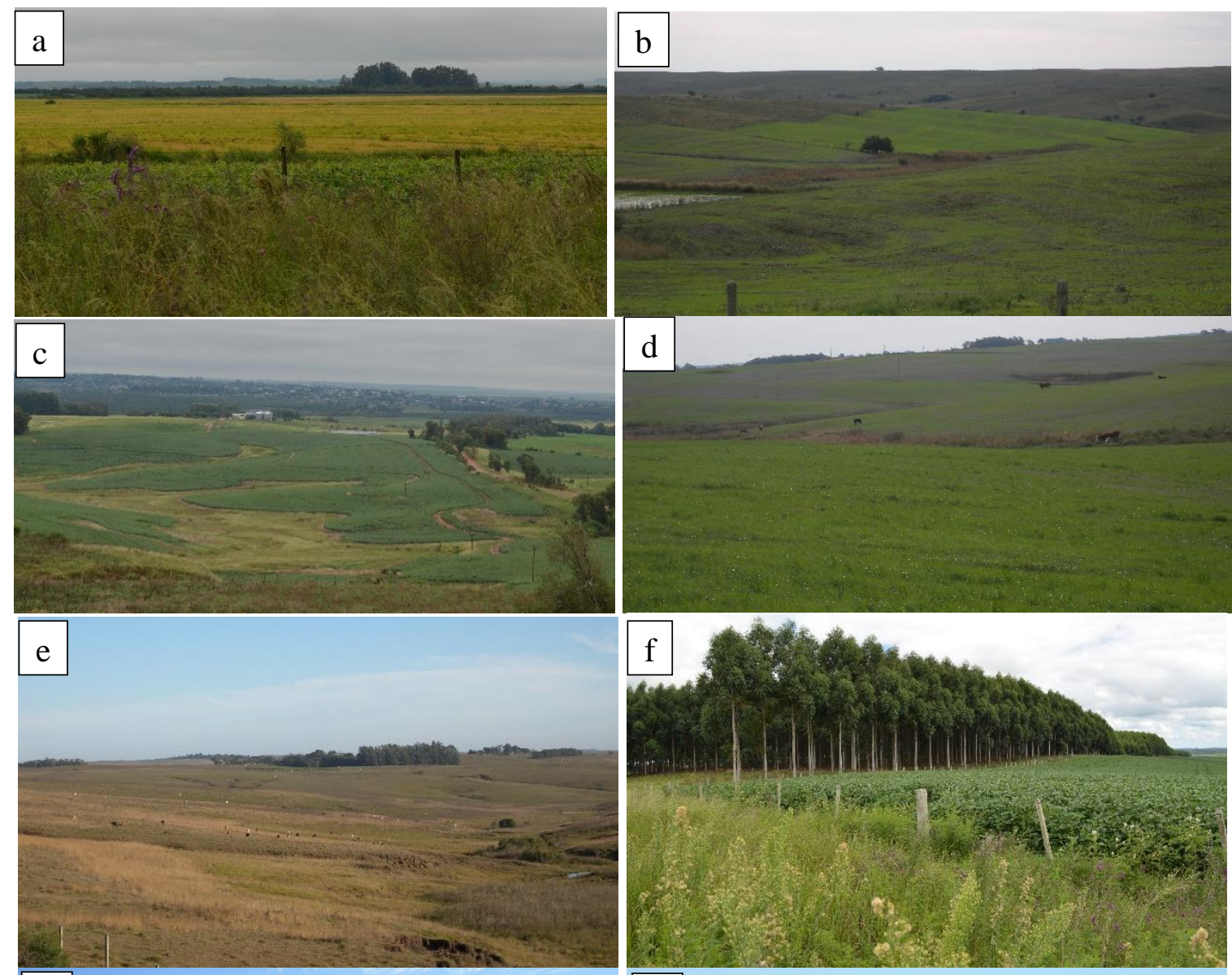

g
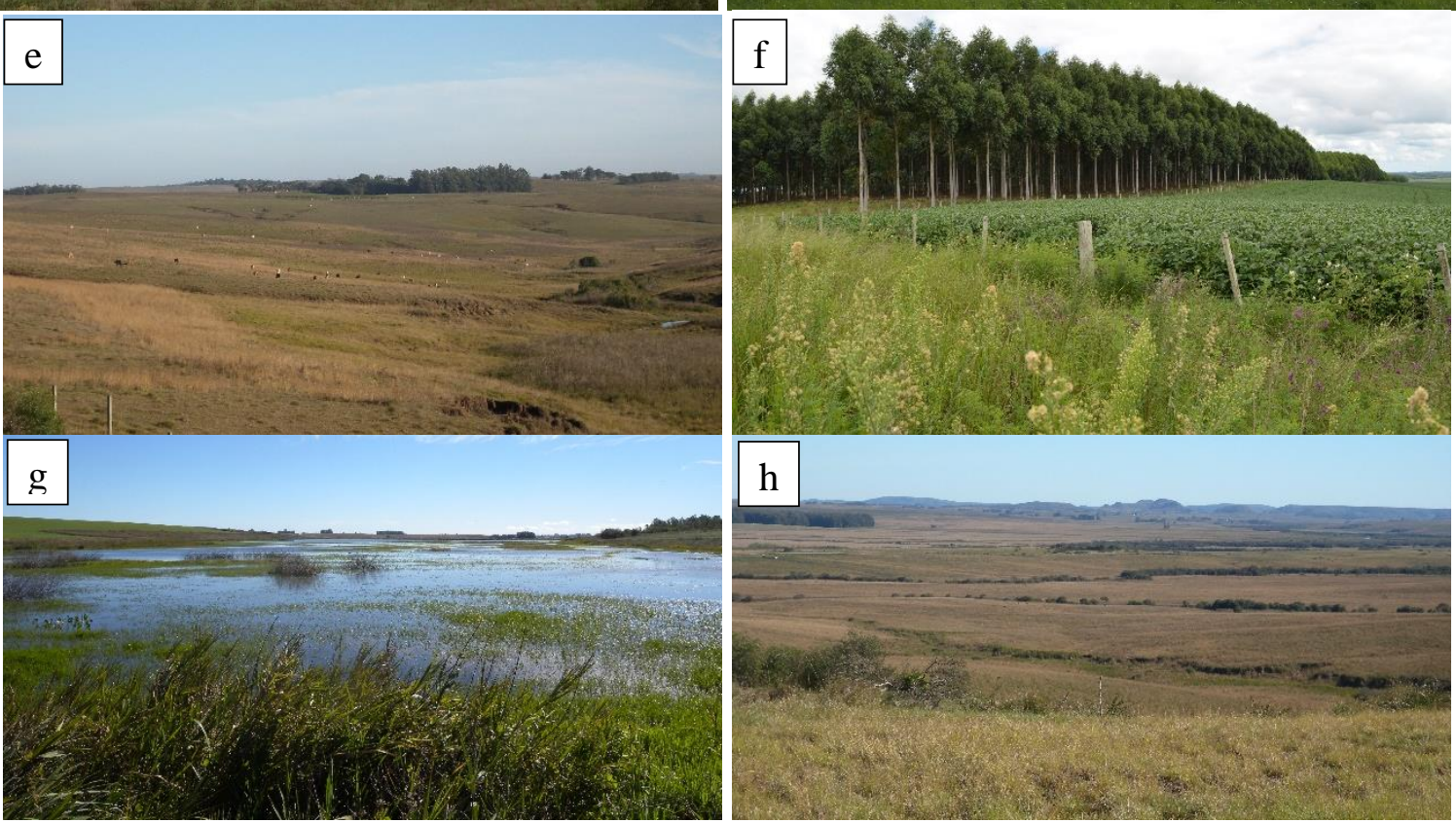

$\mathrm{h}$

Org: os autores

Figura 10 - Distribuição espacial das Unidades de Resposta Hidrológicas nas sub-bacias da área de estudo 


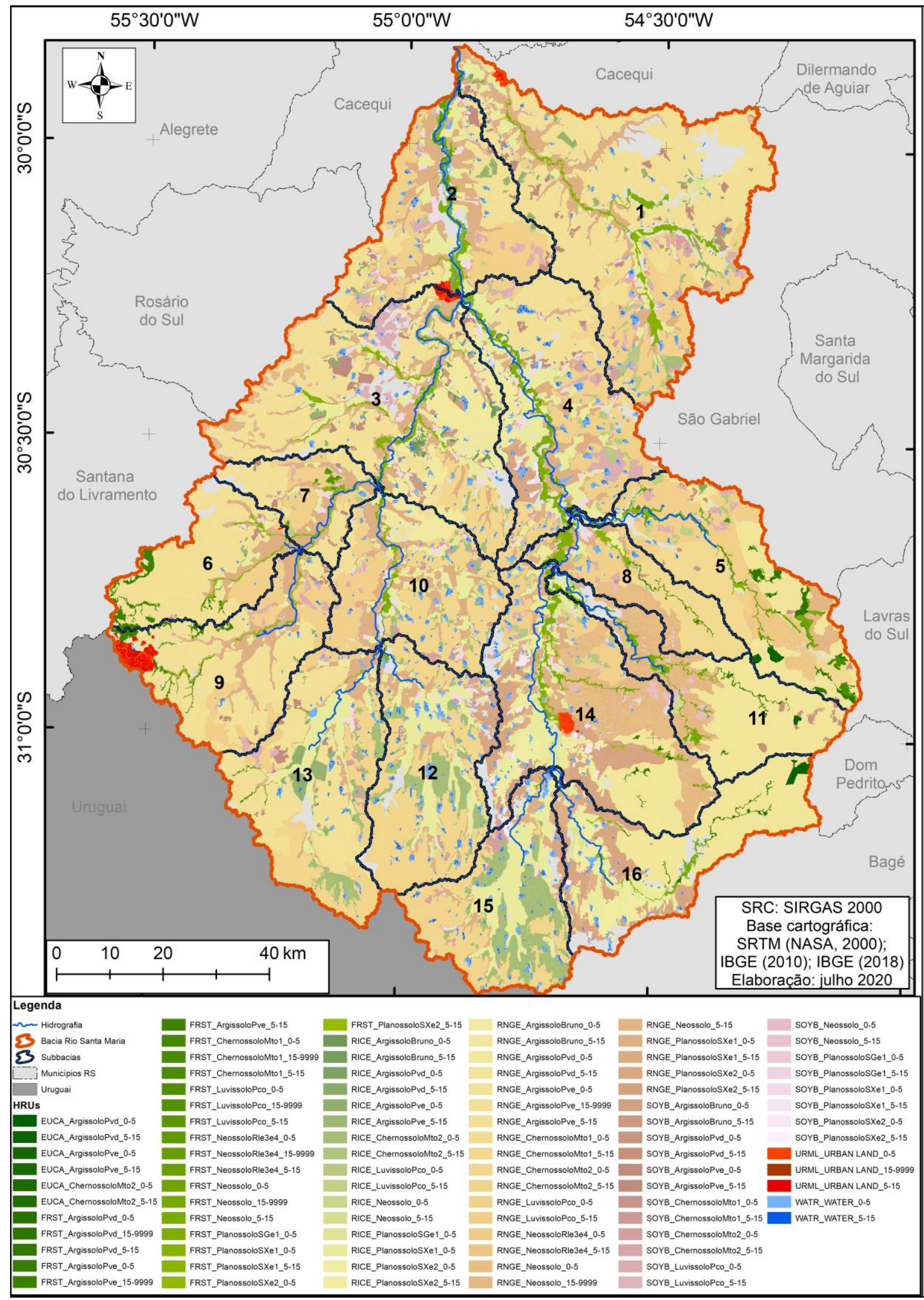

Org: os autores

A sub-bacia 2, área drenada pelo arroio da Divisa e pela Sanga do Areal, localizada as S-SW da bacia apresenta área de $951,81 \mathrm{~km}^{2}$, é constituída por 23 unidades hidrológicas. O relevo é predominantemente 
plano e, junto as drenagens, ocorrem os PlanossolosXe. No relevo ondulado ocorrem Argissolos Pve, nas porções de topo e Luvissolos Tco, que é o solo dominante, na sub-bacia 2, nas áreas planas e na base das vertentes. Os campos com criação são predominantes no relevo ondulado com Argissolos Pve e o cultivo de arroz ocorre junto as drenagens. No extremo NW da sub-bacia ocorrem Neossolos RLE3e4 com áreas de Florestas, ocupando área total de $17 \mathrm{~km}^{2}$. As Florestas, também, ocorrem junto a drenagem principal ocupando área de $38 \mathrm{~km}^{2}$. Uma parte do aglomerado urbano da cidade de Rosário do Sul está incluída nessa sub-bacia.

A sub-bacia 3, drenada pelo Arroio do Salso, Arroio Vacaqua, Sanga Santo Antônio, Sanga dos Varejões e Arroio Tarumã, localizada no SW da bacia, com área de 1563,08 km². Ocorrem 30 unidades hidrológicas. representadas por relevo plano a ondulado e uma porção no extremo oeste com relevo fortemente ondulado. Os solos, predominantes, são os Argissolos variando do Pve (predominante) a Bruno e que se associam, comumente, a Luvissolos Tco na base das vertentes. Os Planossolos Xe1 ocorrem nas áreas de inundação e solos com concentração de matéria orgânica no horizonte superficial (Chernossolos Mto2) ocorrem na base das vertentes sobre um substrato de siltitos marinhos no extremo NE da bacia. Solos raso do tipo Neossolo são importantes na porção oeste da sub-bacia em relevo fortemente ondulado da Serra do Caverá. Nessa sub-bacia o uso e ocupação se caracteriza por áreas de campo com criação e o cultivo é de lavouras de arroz. As florestas ocorrem, principalmente, junto a drenagem principal compondo ao redor de $60 \mathrm{~km}^{2}$ de área. Uma parte da área urbana da cidade de Rosário do Sul ocorre nessa sub-bacia.

A sub-bacia 4, localizada no E da BHSM, com área de $1131,30 \mathrm{~km}^{2}$ se caracteriza por 27 unidades hidrológicas representativas. Apresenta, predominantemente, vertentes menores que $5 \%$ caracterizando como um relevo plano. O relevo plano forma solos do tipo Planossolos $\mathrm{Xe} 1$ como dominante e secundariamente Luvissolos Tco. No relevo ondulado predominam Argissolos Pve e na porção mais a leste da sub-bacia ocorrem Chernossolos Mto2, solos medianamente profundos, com cores bruno escuras, imperfeitamente drenados sendo muito plástico e muito pegajosos, sobre siltitos marinhos. $\mathrm{O}$ uso e ocupação da terra está representado por campos e cultivo de soja nas colinas é significativo. O cultivo de arroz (RICE) ocorre nas áreas de planície de inundação. Áreas com florestas ocorrem na drenagem ocupando área de $59 \mathrm{~km}^{2}$.

A sub-bacia 5, localizada na porção Leste da bacia, com área de $888,60 \mathrm{~km}^{2}$, drenada pelo Arroio Jaguari. A sub-bacia se caracteriza por 42 unidades hidrológicas, onde o relevo ondulado predomina. Os Luvissolos Tco se concentram no baixo curso da sub-bacia associados a substratos de lamitos marinhos, enquanto, os Argissolos Pvd ocorrem no médio curso sobre substrato granito-gnaissico, se caracterizando por solos profundos, avermelhados, textura superficial arenosa, friáveis e bem drenados. No alto curso em declividades mais elevadas ocorrem Neossolos e em porções menos inclinadas são comuns solos do tipo Chernossolo Mto1, solos medianamente profundos, moderadamente drenados, com cores escuras nos horizontes superficiais e bruno amarelados nos mais profundos, textura média e friáveis. $\mathrm{O}$ uso e ocupação é de campos com criação e o cultivo de soja ocorre no relevo ondulado e arroz nas áreas planas. As florestas ocorrem em $82 \mathrm{~km}^{2}$ sendo $39 \mathrm{~km}^{2}$ na drenagem e $17 \mathrm{~km}^{2}$ e nas áreas de Neossolos e afloramento de rochas. Essa sub-bacia é onde a ocorrência de florestas é a mais importante com $10 \%$ da área total. Nessa sub-bacia ocorrem reflorestamento de espécies exóticas em uma área de $7 \mathrm{~km}^{2} \mathrm{da}$ bacia.

A sub-bacia 6, drenada pelos arroios da Cruz e arroio Porteirinha, localizada na porção $\mathrm{W}$ da Bacia, apresenta área de $576,28 \mathrm{~km}^{2}$ e é formada por 22 unidades hidrológicas. O relevo plano que predomina está associado a drenagem. O relevo ondulado e fortemente ondulado reflete as colinas e os morrotes da Serra do Caverá. Os solos do tipo Argissolos Pve predominam nas colinas e ocorrem associados a Argissolos Pvd e Neossolos. Luvissolos Tco se associam aos interflúvios a leste da drenagem principal onde ocorrem rochas sedimentares lamíticas. $\mathrm{O}$ uso do solo predominante são áreas de campo com criação (RNGE). As florestas ocorrem em $41 \mathrm{~km}^{2}$ sendo $31 \mathrm{~km}^{2}$ nas áreas de cabeceiras e associadas ao relevo fortemente ondulado e $10 \mathrm{~km}^{2}$ associado a rede de drenagem.

A sub-bacia 7, drenada pelo arroio Taruma e arroio do Beco, localizada na porção W da BHRSM, com área de 349,86 km² representa a menor sub-bacia da bacia do rio Santa Maria e está constituída por 18 unidades de resposta hidrológica. O relevo predominante é plano que segue as planícies aluviais. O relevo ondulado forma as colinas da região de interflúvio e no extremo oeste ocorrem morrotes e morros caracterizados por vertentes com declividades superiores a $15 \%$. Os Argissolos Pve, predominantes, ocorrem no relevo de colinas e na baixa vertente e associado as áreas planas ocorrem Luvissolos Tco e os Planossolos SXe1 mais próximos aos canais fluviais. As vertentes inclinadas a oeste ocorrem solos mal desenvolvidos do tipo Neossolos. O cultivo de arroz (RICE) é importante nas áreas de planície de inundação sobre solos do tipo Planossolo e Luvissolos. Áreas de campo predominam e o cultivo de soja

\begin{tabular}{llllll}
\hline Caminhos de Geografia & Uberlândia - MG & v. 22, n. 84 & Mês/Ano & p. 269-284 Página 280
\end{tabular}


ocorrem, especialmente associado a Luvissolos. As florestas ocorrem em $18 \mathrm{~km}^{2}$ associado a rede de drenagem.

A sub-bacia 8, drenada pelo arroio Santo Antônio, localizada na porção Centro-E, apresenta uma área de $422,60 \mathrm{~km}^{2}$, com 24 unidades de resposta hidrológica. O relevo é plano onde as vertentes predominantes são inferiores a $5 \%$ de declividade, ocorrendo junto a drenagem principal. A Oeste da sub-bacia com solos variando de Luvissolos Tco na base das vertentes para Planossolos Xe1 e alguns Planossolos Ge1 que são solos bastante influenciado pela presença da água que ocasiona fenômenos de redução, com o desenvolvimento no perfil de características de gleização. A Leste da sub-bacia o relevo é ondulado se desenvolvendo em rochas granito-gnaisse e vulcanicas-vulcanoclásticas do embasamento cristalino. Os solos do tipo Chernossolo MTo1 são solos medianamente profundos, com cores escuras nos horizontes superficiais, textura média e friáveis ocorrem, predominantemente, sobre substrato granito-gnáissico, enquanto Neossolos se associam ao terreno vulcânico, onde vertentes com inclinações superiores a 15\% são importantes. Áreas de campo com criação é o principal uso, lavouras de soja ocorrem no relevo de colinas e cultivo de arroz nas áreas de planície de inundação. As florestas ocorrem em $32 \mathrm{~km}^{2}$ associado a rede de drenagem e representam $8 \%$ da bacia.

A sub-bacia 9, drenada pelos arroios Capivara e arroio Florentina, localizada a NW da bacia, tem 23 unidades de resposta hidrológica e área de $812,50 \mathrm{~km}^{2}$. Constituem relevo plano a ondulado, mas com ocorrência de vertentes com inclinações superiores a $15 \%$ na porção oeste da sub-bacia constituindo os morros e morrotes da Serra do Caverá. Solos tipo Argissolos Pve ocorrem no relevo de colinas e na base das vertentes em direção a planície de inundação ocorrem solos do tipo Luvissolo Tco até Planossolos Xe1. O uso e ocupação está associado a áreas de campo com criação. As florestas ocorrem em $33 \mathrm{~km}^{2}$ associado a rede de drenagem e as vertentes de morros e morrotes. O reflorestamento de espécies exóticas está representado em uma pequena área da sub-bacia. Uma parte da área URB da cidade de Livramento está incluída nessa sub-bacia.

A sub-bacia 10, drenada pela sanga do Cursinho, que se localiza no Centro da sub-bacia, possui área de $804,31 \mathrm{~km}^{2}$ e 21 unidades hidrológicas. O relevo plano a levemente ondulado predomina sobre um substrato de lamitos onde os solos são do tipo Chernossolos Mto2, predominante, Luvissolos Pco e Planossolos Xe1. Em uma porção a Norte da sub-bacia ocorre um relevo ondulado, onde se associam vertentes superiores a $15 \%$ e solos são do tipo Argissolos Pve e menor representação de Argissolos Bruno. O uso e ocupação é de campos com criação e o cultivo predominante é de lavouras de arroz. Florestas ocorrem em $18 \mathrm{~km}^{2}$ associado a rede de drenagem.

A sub-bacia 11, drenada pelo arroio Taquarembó, com área de $696,38 \mathrm{~km}^{2}$, se localiza a SE e apresenta 28 unidades hidrológica. O relevo se caracteriza por ondulado sobre um substrato de rochas cristalina do embasamento com solos do tipo Argissolos Pvd. Na porção NW da sub-bacia ocorre um platô de rochas vulcanoclásticas com vertentes com inclinações superiores a 15\% e a formação de Neossolos. Áreas planas ocorrem associada a drenagem principal onde se desenvolvem solos do tipo Luvissolo e Planossolo Xe1 e Ge1. Campo com criação e lavouras de soja são significativos, devido ao relevo ondulado. A ocorrência de florestas com $48 \mathrm{~km}^{2}$ associado a rede de drenagem em pelo menos $28 \mathrm{~km}^{2}$ e a vertentes íngremes $5 \mathrm{~km}^{2}$. Ocorre próximo de $2 \mathrm{~km}^{2}$ de reflorestamento de espécies exóticas.

A sub-bacia 12, drenada pelos arroios Upacarai e Vacaiqua, localizada na porção Centro-SW da BHRS, apresenta área de $892,67 \mathrm{~km}^{2}$ e 16 unidades hidrológicas. O relevo é plano com predominância de vertentes com inclinações menores que $5 \%$. Junto aos canais de drenagem principal formam-se Planossolos Xe1 onde ocorre importantes áreas de cultivo de arroz (RICE). No relevo levemente ondulado dos interflúvios associado a lamitos formam-se solos do tipo Chernossolo MTo2 (unidade Ponche Verde) medianamente profundos, com cores bruno escuras, argilosos, poucos porosos e imperfeitamente drenados. As lavouras são de arroz e se associam a campos com criação. As florestas estão muito degradadas pelas lavouras, ocorrendo em somente $2,5 \mathrm{~km}^{2}$.

A sub-bacia 13, drenada pelo rio Upamaroti, com área de 1013,00km², se localiza a SE-S e está dividida em 29 unidades de respostas hidrológicas. O relevo é levemente ondulado e o substrato de rochas sedimentares variando de arenitos a lamitos. Sobre o relevo ondulado de arenitos predominam os solos do tipo Argissolos vermelho-amarelo PVE, com cores bruno acinzentadas e bruno avermelhadas, franco arenoso no horizonte $\mathrm{A}$ e argilosos no B, e moderadamente drenados. Sobre o substrato lamítico predominam solos medianamente profundos, com cores bruno escuras, argilosos, poucos porosos e imperfeitamente drenados classificados como Chernossolo MTo2. Associados a planície de inundação ocorrem Planossolo SxE1 que apresentam teores elevados da fração silte, mas também com regulares proporções de argilas expansivas, daí sua plasticidade e pegajosidade. O uso e ocupação é de campos com criação, alguma soja nas colinas e um grande cultivo de arroz nas planícies. Devido ao uso elevado

$\begin{array}{llllll}\text { Caminhos de Geografia } & \text { Uberlândia - MG } & \text { v. 22, n. 84 } & \text { Mês/Ano } & \text { p. 269-284 } & \text { Página } 281\end{array}$


da área para lavouras, as florestas ocorrem em somente $4,6 \mathrm{~km}^{2}$ da sub-bacia, mas existem $0,5 \mathrm{~km}$ de reflorestamento de espécies exóticas.

A sub-bacia 14, drenada pelo arroio Taquarembó Chico, pelo arroio Santa Maria Chico, sanga Preta e arroio do Salso, está localizada no Centro-S da BHSM, com área de 1295,14km² e 35 unidades hidrológicas. O relevo é predominantemente plano, mas ocorre na sua porção leste sobre substrato de rochas cristalinas do embasamento com relevo ondulado definido por vertentes entre $5-15 \%$ mas com porções onde as vertentes apresentam declividade superior a 15\%. Na área plana próximo as drenagens os solos são medianamente profundos, imperfeitamente drenados, com cores bruno e acinzentadas nos horizontes superficiais e amareladas nos mais profundos, com predomínio da fração silte, mas também com regulares proporções de argilas expansivas classificados como Planossolo SxE1 e, menos comumente, solos mal a imperfeitamente drenados, bastante influenciados pela presença da água, o que ocasiona fenômenos de redução, com o desenvolvimento no perfil de cores cinzentas, características de gleização (Planossolo SgE1). Mais afastado da rede de drenagem ocorrem solos negros, imperfeitamente drenados, com nítido contraste entre os horizontes (Planossolo SxE2). Essas áreas planas têm como uso o cultivo de arroz. No relevo ondulado sobre rochas cristalinas os solos são do tipo Neossolos e Argissolo vermelho PVD que são solos profundos, avermelhados, textura superficial arenosa, friáveis e bem drenados. Na base das vertentes podem ocorrer Luvissolos Tco. Associado ao relevo ondulado o uso é de lavouras de soja, mas principalmente criação de gado nos campos. A área urbana da cidade de Dom Pedrito está dentro dessa sub-bacia. As florestas ocorrem em área de $54 \mathrm{~km}^{2}$ da sub-bacia, sendo aproximadamente $45 \mathrm{~km}^{2}$ nas drenagens e $9 \mathrm{~km}^{2}$ associado a vertentes íngremes.

A sub-bacia 15, drenada pelo rio Ponche Verde, com área de $780,63 \mathrm{~km}^{2}$, se localiza no Sul da BHRSM, com 16 unidades de resposta hidrológica. O relevo é predominantemente plano com vertentes inferiores a $5 \%$ e na área das nascentes o relevo é ondulado. Os Chernossolo MTo2 são predominantes e se caracterizam solos medianamente profundos, com cores bruno escuras, argilosos, imperfeitamente drenados sendo muito plástico e muito pegajosos quando molhados. Junto a rede de drenagem os solos variam de imperfeitamente drenados, com cores bruno e acinzentadas nos horizontes superficiais e amareladas nos mais profundos com predomínio da fração silte (Planossolos SxE1) a solos negros, imperfeitamente drenados, com nítido contraste entre os horizontes (Planossolo SxE2). O cultivo de arroz predomina e a área de floresta ocorrem em uma pequena área de $0,7 \mathrm{~km}^{2}$, representando $0,1 \%$ da subbacia.

A sub-bacia 16, drenada pelas nascentes do rio Santa Maria e Sanga Funda, localizada a SE da BHRSM, constituída por 28 unidades hidrológicas e com área de $849,51 \mathrm{~km}^{2}$. A sub-bacia se divide em porção leste com relevo ondulado com solos do tipo Argissolo vermelho PVD solos profundos, avermelhados, textura superficial arenosa, friáveis e bem drenados com uso de lavouras de soja e uma área com reflorestamento de espécies exóticas com, aproximadamente, $10 \mathrm{~km}^{2}$. A porção oeste da sub-bacia tem relevo plano com os solos imperfeitamente drenados, com cores bruno e acinzentadas nos horizontes superficiais e amareladas nos mais profundos, com predomínio da fração silte, mas também com regulares proporções de argilas expansivas classificados como Planossolo SxE1 e solos negros, imperfeitamente drenados, com nítido contraste entre os horizontes (Planossolo SxE2). Ocorrem, também, solos bastante influenciados pela presença da água, o que ocasiona fenômenos de redução, com o desenvolvimento no perfil de cores cinzentas, características de gleização (Planossolo SgE1). Nessa porção predomina cultivo de arroz. A área de floresta está representada por aproximadamente, $25 \mathrm{~km}^{2}$.

\section{CONSIDERAÇÕES FINAIS}

A unidade espacial elementar no modelo SWAT é a unidade de resposta hidrológica (URH) que representa uma combinação do tipo de solo, declividade e uso da terra. A combinação identifica os três elementos e supõem produzir uma resposta hidrológica para cada sub-bacia.

O relevo da Bacia do rio Santa Maria é predominantemente plano a levemente ondulado com vertentes inferiores a $5 \%$ de declividades onde a infiltração é máxima e o escoamento é reduzido. Na sub-bacia 50 relevo é ondulado, com predomínio de vertentes entre 5-15\%, onde o escoamento superficial é significativo. Nas sub-bacias 3, 7 e 9 associadas a Serra do Caverá e na sub-bacia 5 e 11, sobre rochas cristalinas do embasamento, ocorrem vertentes com declividade superiores a $15 \%$, caracterizando áreas de forte escoamento superficial.

Os solos predominantes na bacia do rio Santa Maria são arenosos, moderadamente drenados, classificados como Argissolos Vermelho-Amarelo (Pve), ocorrendo como mais significativo nas sub-bacias 1, 3, 6,7, 9 e 13. Os Argissolos vermelhos (Pvd), que se diferencia dos anteriores por serem mais bem

$\begin{array}{llllll}\text { Caminhos de Geografia } & \text { Uberlândia - MG } & \text { v. 22, n. 84 } & \text { Mês/Ano } & \text { p. 269-284 } & \text { Página } 282\end{array}$


drenados, ocorrem, como predominantes nas sub-bacias 11 e 16. Na sub-bacia 2 o solo predominante é do tipo Luvissolo Tco que têm espessura ao redor de $1 \mathrm{~m}$ e moderadamente drenados, que apresentam um horizonte $A$ proeminente, que transaciona abruptamente para um B textural de coloração bruno avermelhada e vermelho amarelada, argilosa. Os solos do tipo Chernossolo MTo2 são os mais importantes na sub-bacia 15, pela influência dos lamitos marinhos se caracterizam por medianamente profundos, com cores bruno escuras, argilosos, imperfeitamente drenados, muito plástico e pegajosos. Os Planossolos Sxe1 que se caracterizam por serem imperfeitamente drenados, com cores bruno e acinzentadas nos horizontes superficiais e amareladas nos mais profundos, com teores elevados da fração silte, mas também com regulares proporções de argilas expansivas é o mais importante na subbacia 4.

As áreas de campo predominam em praticamente toda bacia do rio Santa Maria, exceto na sub-bacia 15 onde ocorre predomínio de arroz. As florestas, importantes na distribuição da água nas vertentes, são importantes nas sub-bacias 5 e 8.

A análise das características da BHRSM permitiu avaliar que as unidades de respostas hidrológicas geradas representam de forma satisfatória as heterogeneidades presentes. Para determinação das unidades hidrológicas a dificuldade encontrada se relaciona ao fato de o modelo ter sido projetado para condições de solos e usos do EUA. Para aplicação do modelo, nas condições encontradas no Brasil, é necessário adaptações e modificações no banco de dados que são apresentadas e discutidas no trabalho.

Dessa forma, acredita-se que se contribuiu na discussão das dificuldades metodológicas para gerar as unidades básicas que irão ser utilizadas na modelagem. As próximas etapas de calibração e validação do modelo SWAT dependem dessa base da qualidade dos dados iniciais geradores dos URH que são utilizados para a operação do modelo.

\section{AGRADECIMENTOS}

Os autores agradecem a Fundação de Amparo à Pesquisa do Rio Grande do Sul (FAPERGS) e ao Conselho Nacional de Desenvolvimento Científico e Tecnológico (CNPq).

\section{REFERÊNCIAS}

ARNOLD, J. G.; SRINIVASAN, R.; MUTTIAH, R. S.; WILLIAMS, J. R. Large area hydrologic modeling and assessment, Part 1: Model Development. JAWRA. 1998, 34(1), 73-90.

BONUMÁ, N. B. 2011. Modeling of water, sediment and phosphorus loads in an agricultural watershed in southern Brazil. PhD diss. Santa Maria, Brazil: Federal University of Santa Maria.

BONUMÁ, N. B.; ROSSI, C. G.; ARNOLD, J. G.; REICHERT, J. M.; PAIVA, E. M. C. D. Hydrology evaluation of the Soil and Water Assessment Tool considering measurement uncertainty for a small watershed in Southern Brazil. Appl. Eng. Agric., v.29, n. 2, p. 189-200, 2013.

BRESSIANI, D. A.; GASSMAN, P. W.; FERNANDES, J. G.; GARBOSSA, L. H. P.; SRINIVASAN, R.; BONUMA, N. B.; MENDIONDO, E. M. Review of soil and water assessment tool (SWAT) applications in Brazil: challenges and prospects. International Journal of Agricultural and Biological Engineering. Beijing, Vol. 8, No. 3, 2015. Disponível em: <https://ijabe.org/index.php/ijabe/article/download/1765/pdf>. Acesso em: 04 set. 2015.

BRASIL. Lei no 8.629, de 25 de fevereiro de 1993. Dispõe sobre a regulamentação dos dispositivos constitucionais relativos à reforma agrária, previstos no Capítulo III, Título VII, da Constituição Federal. Diário Oficial [da] República Federativa do Brasil, Brasília, DF, 26 fev. 1993.

\section{DSG - DIRETORIA DE SERVIÇO GEOGRÁFICO. Banco de Dados Geográficos do Exército.}

Versão 3.0. 2013. Disponível em: <http://www.geoportal.eb.mil.br/mediador/>. Acesso em: 03 jun. 2020.

FAUCONNIER, Y. Avaliação e gestão da água sustentável: A experiência SWAT de modelagem hidrológica (Soil and Water Assesment Tool) na bacia do lbicuí. Master Geografia/Planejamento - Políticas de Desenvolvimento Sustentável Territoriais. Universidade de Maine - Le Mans - França, 2017.

GASSMAN, P. W.; REYES, M. R.; GREEN, C. H.; ARNOLD, J. G. The soil and water assessment tool: Historical development, applications, and future research directions. Trans. ASABE, 50, 2007. 1211-1250.

$\begin{array}{llllll}\text { Caminhos de Geografia } & \text { Uberlândia - MG } & \text { v. 22, n. } 84 & \text { Mês/Ano } & \text { p. 269-284 Página } 283\end{array}$


GARBOSSA, L. H. P.; VASCONCELOS, L. R.; LAPA, K.; BLAINSKI, E. The use and results of the Soil and Water Assessment Tool in Brazil: A review from 1999 until 2010". In: INTERNATIONAL SWAT CONFERENCE, 2011, Toledo. Anais...Toledo, Espain: University of Castilla La Mancha 2011. p. 1-27.

IBAMA - Instituto Brasileiro do Meio Ambiente e dos Recursos Naturais Renováveis. Resolução CONAMA № 001, de 23 de janeiro de 1986. Brasil: DOU. 23 de janeiro de 1986.

IBGE - Instituto Brasileiro de Geografia E Estatística. Projeto Radambrasil. Levantamento de recursos naturais (Folha SH.22 Porto Alegre e parte das Folhas SH.21 Uruguaiana e SI.22 Lagoa Mirim) Rio de Janeiro: IBGE. 1986. Disponível em <https://ibge.gov.br/>. Acesso em: 18 dez. 2019.

Mapa exploratório de solos do estado do Rio Grande do Sul. Rio de Janeiro: IBGE. 2002. Disponível em <https://mapas.ibge.gov.br/>. Acesso em: 04 set. 2015.

Cobertura e uso da terra do estado do Rio Grande do Sul. Rio de Janeiro: IBGE. 2010. Disponível em <https://mapas.ibge.gov.br/>. Acesso em novembro de 2019.

Manual Técnico de Pedologia. - 3. ed. - Rio de Janeiro: IBGE, 2015. 430 p.

Malha de municípios. Rio de Janeiro: IBGE, 2018. Disponível em <https://mapas.ibge.gov.br/>. Acesso em: 03 jun. 2020.

IPT - Instituto de Pesquisas Tecnológicas. Mapeamento Geomorfológico do Estado de São Paulo. São Paulo. Escala 1:500.000, v. 2, 1981. p.130.

MINISTÉRIO DA AGRICULTURA. Levantamento de Reconhecimento dos Solos do Estado do Rio Grande do Sul. Departamento Nacional de Pesquisa Agropecuária/ Divisão de Pesquisa Pedológico Boletim Técnico N. ${ }^{\circ} 30.1973$.

NASA - National Aeronautics and Space Administration. Shuttle Radar Topography Mission (SRTM). California: Jet Propulsion Laboratory. 2000. Disponível em:

$<$ https://lpdaac.usgs.gov/sites/default/files/public/measures/docs/SRTM Quick Guide.pdf>. Acesso em: 19 fev. 2019.

OLIVEIRA, M. Q. C.; MEDEIROS, Y. D. P. Aplicação do modelo SWAT na avaliação de impactos decorrentes da modificação no uso do solo em bacias hidrográficas. In: SIMPÓSIO BRASILEIRO DE RECURSOS HÍDRICOS, 13, 1999, Belo Horizonte. Anais... Belo Horizonte, MG. Associação Brasileira de Recursos Hídricos.1999. p. 1 - 25.

RENNO, C. D.; SOARES, J. V. Modelos Hidrológicos para Gestão Ambiental. Relatório Técnico Parcial, INPE, dezembro 2000. Disponível em

<http://www.dpi.inpe.br/geopro/modelagem/relatorio_modelos_hidrologicos.pdf>. Acesso em: 04 jul. 2016.

RODRIGUES, E. L.; ELMIRO, M. A. T.; BRAGA, F. A.; JACOBI, C. M.; ROSSI, R. D. Impact of changes in land use in the flow of the Pará River Basin, MG. Revista Brasileira de Engenharia Agrícola e Ambiental, 19(1):70-76, 2015.

SAXTON, K. E.; RAWLS, W. J. Soil water characteristic estimates by texture and organic matter for hydrologic solutions. Soil Science Society of America Journal, 70: 1569-1578, september-october 2006.

STONE ENVIRONMENTAL INC \& TEXAS A\&M. ArcSWAT version 2012. Spatial Scniences Laboratory and Blackland Research and Extension Center. Texas A\&M University System. 2012. Disponível em: <https://swat.tamu.edu/software/>. Acesso em: 04 jul. 2019.

TUCCI, C. E. M. Modelos hidrológicos. Porto Alegre, Ed. Universidade UFRGS, 1998.

TUCCI, C. E. M. (Org.) Hidrologia: ciência e aplicação. Coleção ABRH de Recursos Hídricos, v. 4, 3. ed. Porto Alegre: Ed. UFRGS, ABRH, 2002. 943 p.

UZEIKA, T.; MERTEN, G. H.; MINELLA, J. P. G.; MORO, M. Use of the swat model for hydrosedimentologic simulation in a small rural watershed. Revista Brasileira de Ciência do Solo, 36(2):558566, 2012.

Recebido em: 03/09/2020

Aceito para publicação em: 17/12/2020 